\title{
First Record of Venturia sp. Parasitizing the Coconut Moth
}

\author{
Abel Felipe Oliveira Queiroz, Bianca Giuliano Ambrogi ${ }^{\bowtie}$, Jucileide Lima Santos \& Eduardo Silva Nascimento
}

Universidade Federal de Sergipe, e-mail: abelfelipi@gmail.com, bianca.ambrogi@gmail.com (Autor para correspondência ${ }^{\bowtie}$ ), jucileide_jucy@hotmail.com, eduardo_sn1@hotmail.com.

\section{EntomoBrasilis 8 (2): 165-167 (2015)}

Abstract. The coconut moth Atheloca subrufella Hulst (Lepidoptera: Phycitidae) is considered an important pest of coconut crops in Brazil, which is the fourth largest global coconut producer. Concerning the economic importance of this crop and aiming to increase the knowledge related to biological control, the present research aimed records the first occurrence of Venturia sp. (Hymenoptera: Ichneumonidae) parasitizing A. subrufella caterpillars in the State of Sergipe, Brazil. Coconuts infested by A. subrufella caterpillars were collected in coconut plantation and kept in the Entomology Laboratory (Universidade Federal de Sergipe - UFS) until the emergence of A. subrufella adults or the parasitoids. The parasitoids obtained were identified as Venturia sp..

Keywords: Atheloca subrufella; biological control; Cocos nucifera; natural enemy; parasitoid.

\section{Primeira Ocorrência de Venturia sp. Parasitando a Traça-do-Coqueiro}

Resumo. A traça-do-coqueiro Atheloca subrufella Hulst (Lepidoptera: Phycitidae) é considerada uma importante praga da cultura do coqueiro no Brasil, o qual é o quarto maior produtor mundial de coco. Devido à importância econômica desta cultura e visando aumentar o conhecimento relacionado ao controle biológico, o presente trabalho teve como objetivo relatar a primeira ocorrência de Venturia sp. (Hymenoptera: Ichneumonidae) parasitando lagartas de A. subrufella no estado de Sergipe, Brasil. Cocos infestados por lagartas de A. subrufella foram coletados em plantações de coco e mantidos no laboratório de Entomologia (Universidade Federal de Sergipe - UFS) até a emergência de adultos de A. subrufella ou dos parasitoides. Os parasitoides obtidos foram identificados como Venturia sp..

Palavras-Chave: Atheloca subrufella; Cocos nucifera; controle biológico; inimigo natural; parasitoide.

ר The coconut tree, Cocos nucifera Linnaeus (Arecaceae) is among the most widespread fruit trees in the world, occurring practically in all continents. Currently, Brazil is the fourth largest global coconut producer, having a production about 2.8 million tons in a 287,000 ha area (MARTINS \& JESUS JUNIOR 2011). Among the ten largest coconut producer states in Brazil, seven of them are in the northeast region. The largest producer state is Bahia, followed by Sergipe and Ceará that together are responsible for more than $50 \%$ of coconut production in Brazil (MARTINS \& JESUS JUNIOR 2011).

The coconut moth, Atheloca subrufella Hulst (Lepidoptera: Phycitidae), is considered an important pest in coconut crops in Brazil and its thermal requirements favor infestation throughout the whole year in the Brazilian North and Northeast region (SANTANa et al. 2010). A. subrufella caterpillars can develop inside female flowers, feeding on the carpel, or inside young coconut fruits, feeding on the mesocarp. Externally, infested fruits have feces bound by silk strands. Young coconuts and flowers infested by A. subrufella caterpillars are aborted and fall off, the ones that do not fall off become deformed and have its commercial value reduced (BONDAR 1940; FERREIRA et al. 1998, 2002). These characteristics allow them to escape and survive the insecticide applications. Therefore, complementary strategies such as biological control, should be evaluated to control this pest.

Several insect species, mainly hymenopterans, have been recorded as parasitoids, acting as biocontrol agents of a myriad of insects considered important crop pests (MARCHIORI et al. 2007).
Most species parasitoid hymenopteran are within of superfamily Ichneumonoidea that comprises two cosmopolitan families Braconidae and Ichneumonidae (Quicke 2014).

The objective of the present study was to collect and identify a parasitoid from A. subrufella in the State of Sergipe, Brazil.

Forty coconuts, with signs infestation by A. subrufella caterpillars, were collected in two coconut plantation located in Pirambu City, Sergipe. The coconuts were kept in the Entomology Laboratory (Universidade Federal de Sergipe - UFS) in plastic containers (17 cm height x $13 \mathrm{~cm}$ diameter) covered with voil for aeration until the $A$. subrufella caterpillars leave the coconut and reached the pupal phase. The pupae were isolated in plastic containers (5 $\mathrm{cm}$ height x $6.5 \mathrm{~cm}$ diameter) containing filter paper moistened with distilled water covered with voil, and kept under laboratory conditions $\left(24 \pm 1^{\circ} \mathrm{C}\right.$; $\left.60 \% \mathrm{RH}\right)$ until the emergence of $A$. subrufella adults or the parasitoids.

The prevalence of parasistism was calculated using the formula: $\mathrm{P}=$ parasite pupae/total pupae x 100 (Bush et al. 1997; SALLES 1995).

From the collected coconuts were obtained 24 A. subrufella pupae, being sixteen males and eight females. Among the $A$. subrufella pupae emerged five adult parasitoids, being one adult parasitoid per pupa, two of them emerged from male pupae and three from female pupae. The prevalence of parasitism

Financial Support: CNPq and CAPES 
T observed was 20.83\%. Two parasitoid adults obtained were sent to professor Dra. Angélica Maria Penteado Martins Dias from the Universidade Federal de São Carlos, and were identified as Venturia sp. (Hymenoptera: Ichneumonidae) (Figure 1).

Venturia genus belongs to the subfamily Campopleginae, which is known for the importance of its members in the population control of agricultural pests. Among the genera of Campopleginae, eighteen occur in Brazil (SANDONATO et al. 2010). Two new parasitism occurrences were recorded in this subfamily, the Campoletis genus was found parasitizing caterpillars of Agrotis gypaetina Guenée (Lepidoptera: Noctuidae) and Agrotis malefida Guenée (Lepidoptera: Noctuidae) in alfafa pastures in Argentina (EsTELA 2005). No parasitoid species was previously recorded parasitizing A. subrufella, but the Venturia genus has already been recorded parasitizing other Lepidoptera hosts, such as Cryptoblabes gnidiella Millière (Lepidoptera: Pyralidae) in Brazil, an important pest on grapevine orchards (BisotTo-De-Oliveira et al. 2007), Plodia interpunctella (Hübner) (Lepidoptera: Pyralidae) and Corcyra cephalonica (Stainton) (Lepidoptera: Pyralidae) in England (Salt 1975), all of them belonging to the Pyralidae family.

The parasitoids were identified only until genus due the fact that there is not a current and complete review to the Ichneumonidae family (Estela 2005). This is the first record of Venturia sp. parasitizing A. subrufella pupae. However, to assert that Venturia sp. can act as biological control agent of $A$. subrufella in coconut

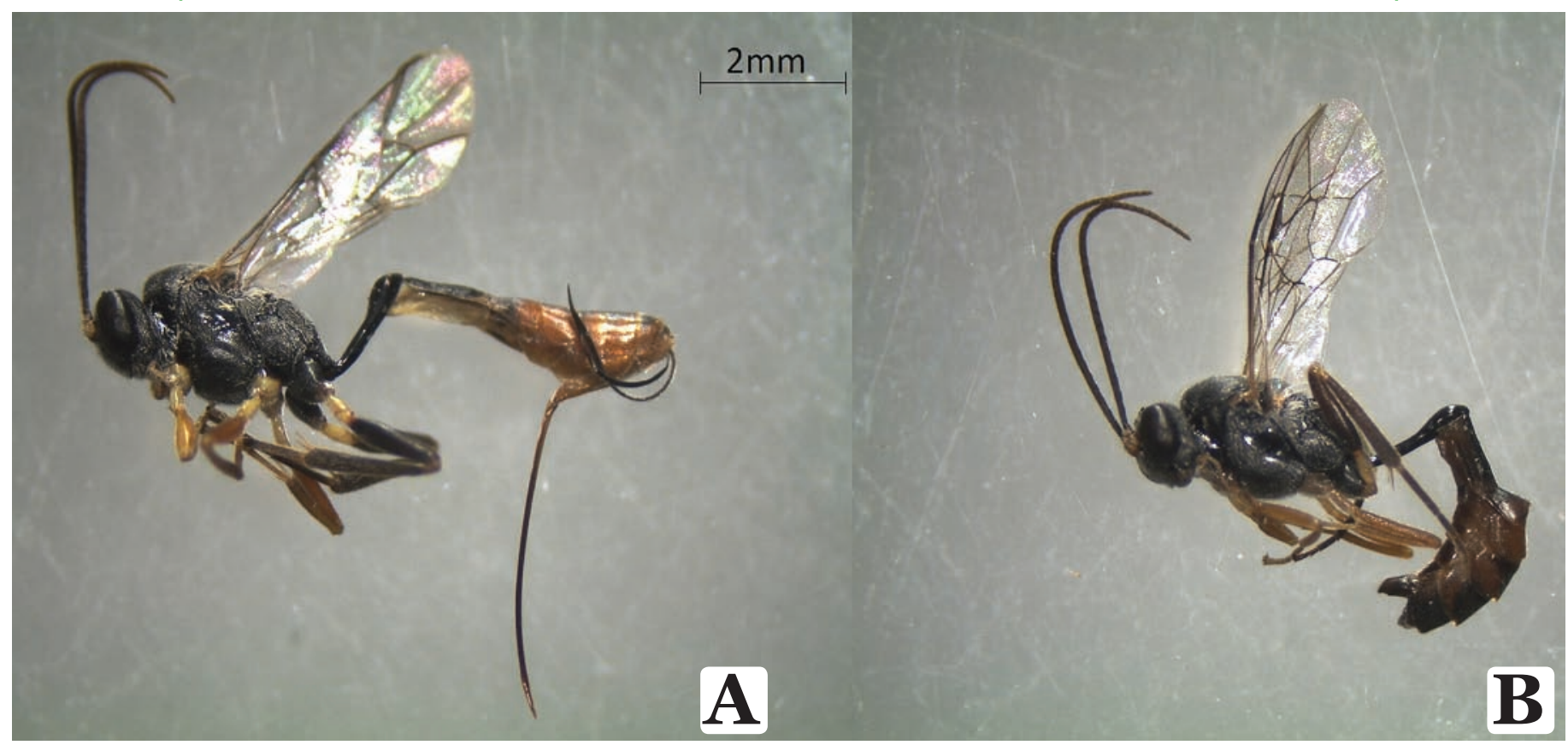

Figure 1. Adults of Venturia sp. sent to identification: side view of (A) a female, which can be identified by the presence of an ovipositor and (B) a male (Queiroz, A.F.O.).

plantations further relevant studies should be conducted.

\section{ACKNOWLEDGMENTS}

The authors are grateful to Dra. Angélica Maria Penteado Martins Dias, an Ichneumonidae taxonomic expert, for the identification of adults parasitoids obtained in the research. The authors thank also to CNPq and CAPES for financial support and scholarship provided for this research.

\section{REFERENCES}

Bisotto-de-Oliveira, R., L.R. Redaelli, J. Sant'ana \& M. Botton, 2007. Parasitóides associados a Cryptoblabes gnidiella (Lepidoptera, Pyralidae) em Videira, RS. Arquivos do Instituto Biológico, 74: 115-119.

Bondar, G.G., 1940. Insetos nocivos e moléstias do coqueiro (Cocos nucifera) no Brasil. Salvador, Tipografia Naval, 160 p.

Bush A.O., K.D. Lafferty, J.M. Lotz \& A.W. Shostak, 1997. Parasitology meets ecology on its own terms: Margolis et al. Revisited. The Journal of Parasitology, 83: 575-583.

Estela, B., 2005. Ichneumonoideos (Hymenoptera) parasitoides del complejo de orugas cortadoras en pasturas de alfalfa (Medicago sativa L.) en la Argentina Central. Neotropical Entomology 34: 407-414. doi: 10.1590/S1519566X2005000300008.

Ferreira, J.M.S., M.F. de Lima, D.L.Q. Santana, J.I.L. Moura \& L.A. de Souza, 1998. Pragas do coqueiro, p. 189-268. In: Ferreira, J.M.S., D.R.N. Warwick \& L.A. Siqueira (Eds.). A cultura do coqueiro no Brasil, 2nd Ed. Brasília, Embrapa-SPI, $292 \mathrm{p}$.

Ferreira, J.M.S., R.P.C. Araújo \& F.B. Sarro, 2002. Insetos e ácaros, p. 10 - 40. In: Ferreira, J.M.S. (Ed.). Coco: fitossanidade (Serie Frutas do Brasil, 28), Brasília, Embrapa Informação Tecnológica, 136 p.

Marchiori, C.H., M.A. Lussari, D.C. Rosa \& A.M. PenteadoDias, 2007. Parasitoid Hymenoptera collected during the diurnal and nocturnal periods in Itumbiara, Goiás. Brazilian Journal of Biology, 67: 581-582. doi: 10.1590/S1519$\underline{69842007000300027 .}$

Martins, C.R. \& L.A. de Jesus Júnior, 2011. Evolução da produção de coco no Brasil e o comércio internacional - Panorama 2010. Aracaju, Embrapa Tabuleiros Costeiros (Documentos, 164), 28p.

Quicke, D.L.J., 2014. The Braconid and Ichneumonid Parasitoid Wasps: Biology, Systematics, Evolution and Ecology. New York, John Wiley \& Sons, 704 p.

Salles, L.A.B., 1995. Estratificação vertical da incidência de Anastrepha fraterculus (Wied.) em fruteiras no sul do Brasil. Anais da Sociedade Entomológica do Brasil, 24: 423-428.

Salt, G., 1975. The fate of an internal parasitoid, Nemeritis canescens, in a variety of insects. Transactions of the Royal Entomological Society of London, 127: $141-161$. doi: 10.1111/ j.1365-2311.1975.tbo0562.x.

Sandonato, D.L., H.C. Onody \& A.M. Penteado-Dias, 2010. Fauna de Campopleginae (Hymenoptera, Ichneumonidae) em hortas orgânicas em Araraquara e São Carlos, SP, Brasil. Biota Neotropica, 10: 117 - 121. doi: 10.1590/S1676- 
06032010000200014.

Santana, S.W.J.S., R. Barros, J.B. Torres \& M.G.C. Gondim Jr, 2010. Exigências térmicas da praga do coqueiro Atheloca subrufella (Hulst) (Lepidoptera: Phycitidae). Neotropical Entomology, 39: 181 - 186. doi: 10.1590/S1519566X2010000200006.
Received in: 05/03/2015

Accepted in: 06/11/2015

\section{Suggested citation:}

Queiroz, A.F.O., B.G. Ambrogi, J.L. Santos \& E.S. Nascimento, 2015. First Record of Venturia sp. Parasitizing the Coconut Moth. EntomoBrasilis, 8 (2): $165-167$.

Available in: $\underline{\text { doi:10.12741/ebrasilis.v8i2.527 }}$
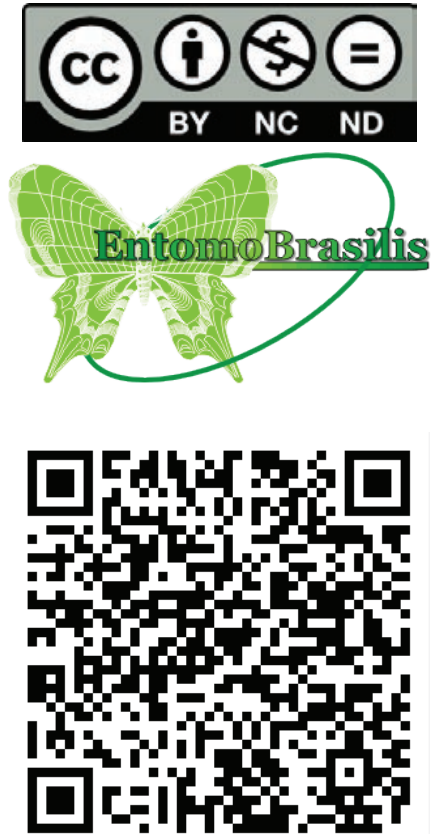